Canadian Journal of Higher Education

Revue canadienne d'enseignement supérieur

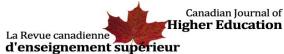

\title{
Book Review of "Disability in Higher Education: A Social Justice Approach"
}

\section{Lydia Boyko}

Volume 49, Number 1, 2019

URI: https://id.erudit.org/iderudit/1060830ar

DOI: https://doi.org/10.7202/1060830ar

See table of contents

Publisher(s)

Canadian Society for the Study of Higher Education

ISSN

2293-6602 (digital)

Explore this journal

Cite this review

Boyko, L. (2019). Review of [Book Review of "Disability in Higher Education: A

Social Justice Approach"]. Canadian Journal of Higher Education / Revue

canadienne d'enseignement supérieur, 49(1), 176-178.

https://doi.org/10.7202/1060830ar 


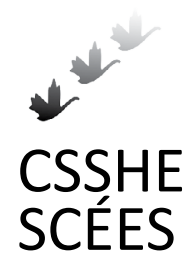

Canadian Journal of Higher Education Revue canadienne d'enseignement supérieur

Volume 49, No. 1, 2019, pages 176 - 178

\section{Book Review / Compte rendu}

Evans, Nancy J., Broido, Ellen M., Brown, Kirsten, R., and Wilke, Autumn, K. (2017). Disability in Higher Education: A Social Justice Approach. San Francisco, CA: John Wiley \& Sons, Inc. (Jossey-Bass). Pages: 515. Price: 54.0o CAD (hardcover).

Reviewed by Lydia Boyko, Professor, School of Media Studies \& Information Technology, Humber College Institute of Technology \& Advanced Learning

The four authors of this encyclopedic tome of 515 pages offer a refreshing, personal and evidence-based perspective on the subject of disability in higher education, which they say is typically associated with the impressions of "deficit", "limitation" and/or "inability."

This book treats the notion of "disability" differently, anchoring it in the concept of "social justice," starting with the assumption that people's abilities and rights to contribute to and benefit from higher education do not depend "on their bodies or psyches conforming to dominant forms" (p. xiii).

Also different is the authors' honest disclosure of their personal lives, which informs and gives credence to their research. Each of the authors self-identifies as "a White, cisgender woman with a great deal of education" (p. xv), with work experience in student affairs and teaching - and having one or more disabilities.

The authors take a holistic approach to the topic, examining barriers to higher education success in the structural, organizational, physical and attitudinal aspects of the institutions. Correspondingly, they explore the related challenges as campus-wide issues rather than as the singular responsibility of disability resource providers.

The "social justice approach" described in this book is framed in the context of "inclusivity" across an institution, which creates an environment that reflects the diverse needs of learners and fosters a culture of understanding. The authors argue that higher education institutions are at their best when they invite and adapt to the broadest possible range of individuals who can contribute to the institution while meeting the academic standards. The idea of exclusivity in higher education is no longer appropriate.

The authors maintain that the usual solution to dealing with disabilities tends to focus on accommodations for individual students, which alter the learning environment, modify evaluation formats and introduce specialized technology that allows an individual with a disability to gain access to curriculum and to complete assigned tasks. While noble in intent, 
these adjustments reinforce perceptions of incapacities within the purview of silos relegated to specific departments or services dedicated to "student wellness." Framed within traditional institutional structures, the attendant policies and procedures are often developed by administrators who have not lived the experiences of "disability" in its various forms.

Despite its heft, this compendium is an accessible guide to accessible learning, with practical guidelines, beyond the theory, that can be applied to higher education programs and services. It is well written and effectively formatted, dissecting the content into four parts and 15 chapters.

The first part advances foundational definitions and disability models (moral, medical, functional, rehabilitative, social and interactionist) in addition to categories and labels of impairment and disability. Significant qualitative and quantitative data and analyses are provided on invisible impairments and disabilities such as digestive, musculoskeletal and hematological, in addition to cognitive incapacities; and on the visible infirmities such as sight, speech and mobility.

The second part examines multiple aspects of identity (including gender, race, sexuality, self-worth and pride); student populations and their respective characteristics (adult, transfer, first-generation, international, parenting, athletes and war veterans); and faculty and staff with disabilities (experiences, perspectives and barriers).

The third part looks at the campus environment (physical and organizational); the campus climate; universal design principles; assistive and learning technology; and instructional classroom interventions.

The fourth part features disability resources in place today across the spectrum of institutions in the United States, including student affairs activities.

Each chapter ends with insightful discussion questions for higher education faculty and administrators. For example, in the chapter on transitions and student affairs, areas for dialogue centre on supports for students moving across programs and institutions.

A highlight is located in the conclusion, notably, seven core principles of a socially just approach to disability in the higher education context. Among these is the primary focus on the ways power and privilege shape the lives of disabled and nondisabled people in higher education, and the explicit recognition of the dangers of staying with the status quo in teaching and learning and disengaging learners.

The discussion of universal design (UD) in education is particularly instructive. The authors concede that this model of instruction can be complicated and difficult to implement. Unlike "deficit-based models," UD advances the premise that individuals possess a wide range of skills, interests and needs. Nurturing a classroom climate and physical environment conducive to universal design requires strategies for curricula, teaching and assessment. This said, the authors also argue that UD need not be unviable or costly. Practical examples of how to attempt to achieve the UD imperatives and to personalize a class include greeting students at the classroom door as they arrive, learning their names, and providing options for class exercises and evaluations such as multi-media projects. Ultimately, these small steps foster interaction between and among the professor(s) and student(s), giving the student(s) a sense that the instructor cares about them as people.

This evaluation underscores a 2016 Canadian/Israeli study of sustainability of disability-related services and UD in higher education, where the authors found a shift toward UD from standard accommodations (Fichten, Heiman, Havel, Jorgensen, Budd \& King, 
2016). The UD principles espoused in that study reflect the principles discussed in this book, specifically, in the use of multiple teaching tools such as podcasts and video; multiple evaluation methods such as virtual group projects and online quizzes; and multiple engagement pathways such as wikis and online mind mapping.

While American in content, including statistical data and examples, the theory and recommendations in this book are relevant in the Canadian context, where more than 11 per cent of the higher education student population has disclosed some form of disability (Association of Canadian Community Colleges, 2014; Association of Universities and Colleges of Canada, 2014). Indeed, the American examples reflect the essence of the various provincial and territorial human rights codes and accessibility legislation and regulations in Canada today.

According to the Canadian Survey on Disability, 2017, youth with disabilities are at a higher risk of not being in school. Understanding the type of disability and its severity is important for supporting youth in making the transition into post-secondary education (Statistics Canada, 2018).

In a recent report on access to higher education in Ontario, the Higher Education Quality Council of Ontario (HEQCO) found that students with disabilities, similar to firstgeneration, low-income and Indigenous students, are less likely to participate in postsecondary education, and less likely to attain a university/college credential than their peers (Deller, Kaufman \& Tamburri, 2019). The HEQCO study recommendations centre on an equity-of-access model that focuses on whether all Ontario youth have an equal opportunity to access and succeed in the post-secondary system. A similar consideration is discussed in the American context in this book.

Ultimately, this book adds to the body of knowledge in higher education, highlighting core concerns and providing practical tools to promote an inclusive mind-set across the post-secondary education spectrum. The concepts are inherently universal.

\section{References}

Association of Canadian Community Colleges (2014). The Association of Canadian Community Colleges - Annual report 2013-14. Ottawa, ON. Retrieved from http:// www.collegesinstitutes.ca/wp-content/uploads/2014/o5/accc_ENG_annual_ report_2013-14_may25.pdf

Association of Universities and Colleges of Canada. (2014). Canadian universities. Retrieved from http://www.aucc.ca/canadian-universities

Deller, F., Kaufman, A., \& Tamburri, R. (2019). Redefining access to postsecondary education. Toronto, ON: Higher Education Quality Council of Ontario.

Fichten, C.S., Heiman, T., Havel, A., Jorgensen, M., Budd, J., \& King, L. (2016). Sustainability of Disability-Related Services in Canada and Israel: Will the real universal design please stand up? Exceptionality Education International, 26, 19-35. Retrieved from http://ir.lib.uwo.ca/eei/vol26/iss1/2

Statistics Canada (2018). Canadian survey on disability, 2017. Ottawa, ON: Author. Retrieved from https://www150.statcan.gc.ca/n1/daily-quotidien/181128/dq181128aeng.htm 